\title{
Approval Plans: Politics and Performance
}

\section{Robert F. Nardini}

\begin{abstract}
Approval plans, controversial when introduced as a gathering technique during the 1960s and 1970s, have evolved into a focused acquisitions device commonly used in academic libraries. Yet approval plans remain controversial within some libraries because they are inherently political in nature. Approval plans challenge library boundaries, requiring consensus on collection development and acquisitions priorities, cooperation among library departments, cooperation between the library and teaching faculty, and a close partnership with the vendor. Since few concrete performance standards exist, approval plan effectiveness is difficult to measure. Perceived difficulty of measurement contributes to the political nature of an approval plan. As in the past, vendors will play an active role in the evolution of approval plans during the 1990s, when libraries may establish cooperative profiles and add a new dimension to approval plan politics.
\end{abstract}

"Approval and gathering plans are here to stay," predicted Peter SpyersDuran, who in 1968 organized the first conference on this newly developed acquisitions method. ${ }^{1}$ Norman Dudley seconded Spyers-Duran with his 1970 observation, "[I]t seems very clear that ... approval plans are with us to stay." ${ }^{\prime 2}$ The following year a third librarian repeated the comment: "It seems obvious," remarked H. William Axford at the third approval plan conference in 1971, "that the approval plan technique ... is here to stay."

In fact it wasn't obvious in 1971 that approval plans were here to stay. The concept had been established by the Richard Abel Company during the 1960s. Yet in 1969 Norman D. Stevens spoke for many librarians opposed to approval plans when he described them as symptomatic of "a more casual attitude toward the expenditure of funds." 4 His words were mild compared to others. In 1960 Eli
Oboler had described librarians using publisher blanket orders, a forerunner of the approval plan, as having "no sense of values." 5 Stevens himself noted book vendors' "greedy demand for the library dollar." 6 Skepticism grew when the Abel Company failed in 1974 . $^{7}$

Other vendors took up the practice after the demise of Abel, sustaining the approval plan and thus the debate. In 1978 Rose Mary Magrill and Mona East wrote of lowered selection criteria and of booksellers who "set up plans to exploit the situation." ${ }^{18}$ Margaret Dobbyn's dissent was anthologized in a 1979 reader: "The literature even presents various justifications for turning over the selection of what is needed by the university library to a businessman, whose primary interest in the academic community is profit."

Given opinions like these, SpyersDuran, Dudley, and Axford weren't simply reporting fact. They were argu- 
ing in favor of approval plans. Despite the hardy strain of criticism, many librarians agreed with them and the case clearly was won, to the degree that Dobbyn's statement has been the last outright published attack on the approval plan idea. ${ }^{10}$

Certainly today's evidence indicates that approval plans are an accepted way to buy books. When the 1988 volume of H. W. Wilson's Library Literature fixed "Approval plans" as a subject heading, ending seclusion of the topic under "Acquisitions-order processes," a minor badge of legitimacy was awarded. Also in 1988, an Association of Research Libraries (ARL) survey found that over 90 percent of respondents used approval plans. ${ }^{11}$ While statistics are difficult to find, smaller academic libraries also show significant approval plan activity. ${ }^{12}$

The ARL found "striking," nonetheless, a "remarkable diversity of practice." The number of domestic approval plans varied from one to twenty-seven per library. Libraries reported an assortment of approval plan types: comprehensive; university press; specialized plans for certain publishers, subjects, or formats; and other variations. Six ARL members reported no approval plans at all. ${ }^{13}$

The ARL's findings hint that the question of how to use approval plans, even whether to use them, remains alive. Twelve years ago Jennifer Cargill's summary report on the fourth, and most recent, approval plan conference said that they were "now regarded as a reliable and efficient tool."14 Yet one 1988 ARL respondent said that a "vendor's business is selling, not selecting."15 Another reported, "We have found there are no benefits for us and are considering discontinuing the one plan that we now have."16

"It is apparent," the 1988 ARL report very cautiously allowed, "that in certain important respects, approval plans are a stable institution." ${ }^{17}$ Caution had earlier been displayed in a 1982 report. "Apparently," concluded the ARL, echoing Spyers-Duran, "approval plans are here to stay." ${ }^{18}$ With consensus in the literature reached long ago and with wide- spread approval plan use clearly documented, why these refrains from an old debate? Two decades removed from the original words, the ARL's restatements were less a continuation of SpyersDuran's argument than a symptom of librarians' persistent unease with approval plans.

In fact, the debate once published in the literature takes place now more privately, within the walls of some libraries. Approval plans remain controversial because by nature they are inherently political. They raise questions about how library decisions are made and who has authority to make them. Approval plans trespass upon library boundaries: boundaries between teaching faculty and library, between administration and staff, between acquisitions and collection development, between one subject selector and another, and between library and book vendor. Never easily drawn, these lines all may be challenged by a new approval plan or by change in an existing one.

\section{THE POLITICS OF APPROVAL PLANS}

The term library politics acknowledges that approval plans exist in a complex organizational landscape. To avoid the phrase is to slight the talents of the librarians responsible, sometimes in the face of opposition, for running approval plans. Despite a vendor's best work, no library will have a fully effective approval plan without having staff able to forge and maintain consensus on priorities and procedures. Approval plan politics is nothing more than that.

\section{Boundaries between Library Administration and Staff}

One source of tension is disagreement between library administration and staff. "If the staff is opposed to it," recalled former Abel representative Jim Cameron, "you should just say thanks to the library and walk away. It won't work otherwise. If the director make the decision that 'we want the approval plan' and the staff is not in favor of it, the plan won't work in that library." 19 
A 1977 survey found administrators responsible more often than any other library group for the initiation of an approval plan. ${ }^{20}$ In the ARL's 1988 report, savings in staff time was the most common reason stated for having a plan. ${ }^{21}$ Demands upon academic libraries in the 1990s outpace growth in staff, one reason for the continued strength of approval plans in a time of lean budgets. ${ }^{2}$ As in the days of the Richard Abel Company, staff cooperation remains essential to approval plan success.

\section{Boundaries between Teaching Faculty and Library}

Hugh Atkinson, at the first approval plan conference in 1968, reported that a new approval plan at Ohio State had caused professors to feel the library "was somehow pulling a 'fast one' on them." ${ }^{23}$ In a sense the professors were right, since librarians often have seen in approval plans a tactic to gain control over book funds, and, as a 1982 ARL respondent stated, a way "to assert [their] role in collection development over faculty." 24

Particularly institutions with no strong history of book selection by librarians might expect questions when teaching faculty learn that a portion of the usual funding - often viewed as "theirs" - will be diverted toward a program they barely understand. ${ }^{25}$ "Approval plans," remarked a physicist addressing a library conference, only partly tongue-in-cheek, "are schemes designed by librarians to frustrate the faculty and get librarians out of work." 26 In this second arena of approval plan politics, librarians must gain the cooperation of academic departments.

\section{Boundaries between Acquisitions and Collection Development}

Opposition to approval plans often comes from collection development librarians' sensing a loss of control in shipments of books that may anticipate their orders, that may be late in arriving, that a selector may dislike, or that may be wholly unfamiliar. Worse still is the time when a desired book fails to arrive at all. Selecting books in tandem with a distant vendor's staff, and with foreign procedures and standards, may seem an alarming prospect to librarians who consider book selection "the quintessential professional act," as William A. Wortman recently wrote. ${ }^{27}$

Yet there are always skeptics like Daniel Gore, who referred to "the old myth that only they [selectors] were truly qualified to select books for their library." ${ }^{28}$ Acquisitions librarians, apt to hold this less reverent view of selection, often see approval plans as a means to reduce the number of orders their department must process. ${ }^{29}$ But to some acquisitions librarians, approval plans are an avenue through which others can intrude upon their domain. Workflows must accommodate the needs and schedules of selectors visiting the approval review shelf. Returns must be processed, and the most discriminating selectors cause the most work for acquisitions. Vendor selection, a traditional acquisitions prerogative, can change radically, as the lion's share of the monographs budget may go to a vendor chosen by committee.

\section{Certainly today's evidence indicates that approval plans are an accepted way to buy books.}

One approval plan advantage, according to a $1982 \mathrm{ARL}$ respondent, is that the process "forces dialogue between acquisitions staff and selecting librarians." The dialogue isn't always friendly. Achieving balance between acquisitions and collection development priorities is a third element in the politics of approval plans. ${ }^{31}$

\section{Boundaries among Selectors}

When a library buys monographs through firm orders, selectors may be free-constrained only by budget-to define the library's collecting interests as they see fit. But an approval plan requires that the library's needs be explicitly stated in the form of a profile. 
Reaching agreement on profile specifications such as publisher or subject coverage will require negotiation and compromise, since most decisions will affect several selectors and many will affect all. ${ }^{32}$

Budget is another issue. If an approval plan is funded as a single line item, wary selectors will try to prevent too much money from being transferred from their discretionary funds. If approval plan books are charged to selectors' lines, estimating the allotments may be difficult, especially for a new approval plan, since this means predicting how much the vendor will ship.

\section{Despite a vendor's best work, no} library will have a fully effective approval plan without having staff able to forge and maintain consensus on priorities and procedures. Approval plan politics is nothing more than that.

Collection development is a young function in many libraries. Authority lines may be weak for the collection development head. Nonetheless, theneed for some means to achieve consensus within the selecting group comprises the fourth sphere of approval plan politics.

\section{Boundaries between Library and Vendor}

A fifth area of consequence intersects all the rest. Approval plans require that the library and vendor share professional acquisitions and collection development responsibility. No other book-buying method puts the two in such an intimate relationship. Some librarians question that a partnership is possible. How compatible are business values and those of a library? What part does the profit motive play in a vendor's individual and aggregate book selection decisions? Which party truly controls the approval plan?

Competition among vendors for business is another factor in library politics. When vendors compete for a new approval plan or attempt to displace an incumbent rival, the stakes can be high. Beyond financial reward is the less tan- gible prize of prestige; i.e., the satisfaction of winning an important account. Bound up with the vendors' persuasive efforts may be staff's inclinations toward one vendor or another. Vendors will try to use these inclinations to their own advantage. ${ }^{33}$

\section{EVALUATION OF APPROVAL PLAN PERFORMANCE}

"I have had frequent opportunity to ask and be asked," reports Dennis R. Brunning, "how is the approval plan doing?" ${ }^{\prime 3}$ Many librarians might say the same thing. Despite the prevalence of the question, answers will draw nearly always upon impressions, not upon data. Approval plan performance, in comparison to firm order service, is difficult to analyze quantitatively.35 Concrete and widely accepted performance standards hardly exist. Therefore, the case for or against approval plans may proceed on any number of levels, many of them with political overtones.

At the same time, the political nature of approval plans is a contributing reason for the lack of an adequate means of quantifying them. While consensus may have been reached that approval plans are good, the question of why they are good is less easily settled. ${ }^{36}$ Statements in the literature variously assert that speed of delivery is not important, that discount is overemphasized, and that a plan with a 43 percent rejection rate was performing well. ${ }^{37}$

Librarians on the same staff, even within a department, may view an approval plan in an entirely different way. Setting aside staff who participate with reluctance, those who join willingly may do so for differing reasons and may bring their own priorities with them. Whose priorities will prevail? Should librarians seek depth and breadth of coverage (one area of possible disagreement), or should profile precision and a low return rate be the goal?

Librarians aren't likely ever to have a ready equation to calculate approval plan success. Which factors should be rated, and what weight assigned to each? Return rate is often cited, since it 
is easy to measure. But the list of other variables is formidably long: speed of delivery by the vendor, breadth of coverage, depth of coverage, accuracy in observing the profile, billing and shipping accuracy, quality of bibliographic records, quality of management reports, customer service responsiveness, technical services, and discount. The relative importance of these will vary from library to library, and from librarian to librarian.

The political nature of approval plans is a contributing reason for the lack of an adequate means of quantifying them.

While the need for regular monitoring of approval plans has long been recommended, putting an approval plan under formal study will certainly erase any time savings the plan may have won for the staff. Brunning recalls the "countless hours" spent on his study, and Linda Ann Hulbert and David Stewart Curry concluded their research by warning that "the memory of the work involved .... will temper our enthusiasm for embarking on another." ${ }^{38}$ In addition, researchers face a moving target. Since vendor service levels may rise or fall at any time with improvements or disruptions involving staff, facilities, or equipment, results can quickly become obsolete.

\section{A Case Study in Approval Plan Evaluation}

One approach to formal approval plan evaluation is to compare a working plan to a parallel system of selection, the method chosen by Linda Ann Hulbert and David Stewart Curry in their study of a new approval plan at the Health Sciences Library at the University of Iowa. ${ }^{39}$ The library had canceled an earlier plan because "coverage ... appeared unsatisfactory," and the new one faced skepticism..$^{40}$ Alongside the new plan, staff continued to select from book reviews, publisher fliers, and other sources. After three months, their choices were compared to approval receipts. The ap- proval plan brought in 38 percent of selections from fliers and 20 percent from reviews. The record varied widely by publisher and journal.41 Did the plan perform poorly or well? The authors concluded: "We have assured ourselves that the approval plan ... works well for our library." 42

A year later Hulbert, who by then had moved to a different library, repeated the study. She wrote a letter to College \& Research Libraries, acknowledging an absence of benchmarks to put her results in context: "Because the results from the original study could be taken by some as good and by others as mediocre, and, therefore, not conclusively in favor of approval plans, I felt the need to affirm that a good vendor can support a growing collection and that dependency on that vendor is not an abrogation of the collection development responsibility of a library." 43

\section{Comparing Vendors}

Another approach to approval plan evaluation is to compare an incumbent vendor to the competition, by asking one or more firms to operate a shadow approval plan by supplying bibliographic records under specifications as close as possible to the live plan. Because vendors use different methods to construct profiles, it is hard to devise instructions that will have competitors doing exactly the same thing. In addition, researchers must contend with explaining what doesn't happen in a study, as well as describing what does happen. Thus it is far easier to compare speed when all vendors under study treat a given book, than to account for a title handled by one and not another.4

Did one vendor miss the title? Or did the profile, as understood by the vendor, exclude it? Or, did the vendor treat the title before or after the study's time parameters? In their 1989 study of sci/tech approval plans at Texas A\&M University, Gloriana St. Clair and Jane Treadwell demonstrate by their data that these questions will need to be addressed. St. Clair and Treadwell asked four vendors to provide the same subject coverage over 
the same period of time, to find that only 77 of 1,892 titles -4 percent-would have been supplied by all four vendors. ${ }^{45}$

Study design aside, the question persists: how to interpret results? When one vendor supplied 67 percent of the titles treated by another, as Hugh Franklin found at Oregon State University, was this success or failure? ${ }^{46}$ Or was 72 percent, as reported in 1982 at Texas A\&M, a success? ${ }^{47}$ The respective test vendors might have seen things differently, but both results were interpreted favorably toward the incumbents who had treated the smaller number of titles in both instances.

An incumbent vendor-at the very least a familiar name in the library-has every chance to build trust, to form working relationships with all levels of staff, and to defend its approval plan against competing firms by influencing library decisions. Librarians often invest considerable time and effort to establish and maintain an approval plan with their vendor of choice. How many percentage points better will a competing vendor need to be before the original investment is discarded?

\section{Communication between Library and Vendor}

The experience of the University of Nebraska, Lincoln, described by Kay Womacketal., suggests what may happen to a neglectful incumbent. Womack reported persistent dissatisfaction among some staff, yet reluctance from others to part with their vendor of ten years. With a new dean and new acquisitions head, though, the library conducted a review of five vendors and made a decision to change. One lesson learned was "that vigilance must be maintained if the services of the vendor are to be used with skill. It was obvious from the vendor presentations that the Acquisitions staff had not understood the full capabilities of the vendor services. The presentations also revealed the importance of good communication between the vendor and Acquisitions." ${ }^{48}$

"Good communication" between approval plan vendor and library has been a byword in the literature from the start.
When staff confess not to understand vendor capabilities, blame is placed clearly upon the vendor, who cannot have taken advantage of incumbent position to correct this, who must not have formed strong relationships with key staff, and who may have assumed that an arrangement of ten years' standing would stand for ten more.

As vendors compete in a market that is static at best, and as libraries search for efficiencies, the cooperative approval plan may arise.

An attentive vendor is far more likely to pass review. Even if a study uncovers a usually responsible vendor's failure to ship one-third of the titles in a sample of desired new books, a librarian may still conclude that the approval plan "works as it should." ${ }^{\prime 49}$ More than once the bond between library and approval plan vendor has been compared to marriage.$^{50} \mathrm{As}$ the metaphor suggests, the two share a union in which much may be forgiven.

Has trust been achieved? The answer to this question, above any other, is the test of approval plan success or failure. Has trust been achieved within the library? Staff must work closely and communicate clearly for any approval plan to do its job. And has trust been achieved between library and vendor? Each must feel, as the measure of success, that the other has fully invested in a partnership requiring a remarkable level of interaction.

\section{APPROVAL PLANS, PAST AND FUTURE}

Thirty years ago, the approval plan was invented for the mass acquisition of books. Twenty years ago, as library budgets began to shrink, the survival of approval plans was doubtful. But vendors and librarians retooled the approval plan by focusing profiles upon core areas of interest, a shift so successful that published dissent on the method virtually disappeared over ten years ago.

While use today is widespread, there is no reason to think the approval plan's 
evolution is complete. As vendors compete in a market that is static at best, and as libraries search for efficiencies, the cooperative approval plan may arise. The cooperative approval plan may include two or more libraries and a vendor who designs integrated profiles, thus adding a new dimension to approval plan politics. ${ }^{51}$ Joint profiles could only invite joint evaluation and monitoring. That, perhaps, would suggest new yardsticks for performance, fashioned from data jointly gathered on the concrete experience of peer libraries. Whether or not changes like these come about, it is clear Peter Spyers-Duran and all who agreed with him were correct, that approval plans are here to stay.

\section{REFERENCES AND NOTES}

1. Peter Spyers-Duran, "Preface," Approval and Gathering Plans in Academic Libraries, ed. Peter Spyers-Duran (Littleton, Colo.: Libraries Unlimited for Western Michigan University Libraries, 1969), 1.

2. Norman Dudley, "The Blanket Order," Library Trends 18 (Jan. 1970): 326.

3. H. William Axford, "Economics of Approval Plans," in Economics of Approval Plans, ed. Peter Spyers-Duran and Daniel Gore (Westport, Conn.: Greenwood, 1972), 21.

4. Norman D. Stevens, "The Resources and Technical Services Division of ALA," Library Resources \& Technical Services 13 (Summer 1969): 334.

5. Eli Oboler, Reply to survey in "The 'Get-'em-all' Theory of Book Buying," Library Journal 85 (Oct. 1, 1960): 3391.

6. Stevens, "The Resources and Technical Services Division of ALA," 334.

7. Jane Maddox, "Approval Plans-Viable?" Journal of Academic Librarianship 1 (Jan. 1976): 22. For a 1975 case study in approval plan opposition, see Association of Research Libraries, Office of Management Studies, Systems and Procedures Exchange Center, Approval Plans in ARL Libraries, SPEC Kit, no. 83 (Washington, D.C.: ARL, 1982), 79-84. On the Abel Company's history, see the three-part interview by Dora Biblarz, "Richard Abel," Against the Grain 4 (June 1992): 24-27; 4 (Sept. 1992): 20-24; 4 (Nov. 1992): 35-39. See also Lyman W. Newlin, "The Rise and Fall of Richard Abel and Co., Inc.," Scholarly Publishing 7 (Oct. 1975): 55-61.

8. Rose Mary Magrill and Mona East, "Collection Development in Large University Libraries," in Advances in Librarianship, vol. 8, ed. Michael H. Harris (San Diego, Calif.: Academic Press, 1978), 6.

9. Margaret Dobbyn, "Approval Plan Purchasing in Perspective," in Background Readings in Building Library Collections, 2d ed., ed. Phyllis Van Orden and Edith B. Phillips (Metuchen, N.J.: Scarecrow, 1979), 194.

10. Acknowledgment is due on this and other points to Gary J. Rossi, "Library Approval Plans: A Selected, Annotated Bibliography," Library Acquisitions: Practice \& Theory 11 (1987): 3-34. Approval plans in a specific type of library were recently criticized by William J. Hook, "Approval Plans for Religious and Theological Libraries," Library Acquisitions: Practice \& Theory 15 (1991): 215-27.

11. Association of Research Libraries, Office of Management Studies, Systems and Procedures Exchange Center, Approval Plans, SPEC Kit, no. 141 (Washington, D.C.: ARL, 1988), 6.

12. See, for example, L. Hunter Kevil, "The Approval Plan of Smaller Scope," Library Acquisitions: Practice \& Theory 9 (1985): 13-20; Thomas W. Leonhardt, "The Importance of Approval Plans When Budgets Are Lean," in Acquisitions, Budgets and Material Costs: Issues and Approaches, ed. Sul H. Lee, Monographic Supplement no. 2 to Journal of Library Administration (Binghamton, N.Y.: Haworth, 1988), 2; Bart Harloe, "Achieving ClientCentered Collection Development in Small and Medium-Sized Academic Libraries," College \& Research Libraries 50 (May 1989): 344-53.

13. Association of Research Libraries, Approval Plans, 6-9.

14. Jennifer Cargill, "A Report on the Fourth International Conference on Approval Plans," Library Acquisitions: Practice \& Theory 4 (1980): 111.

15. Association of Research Libraries, Approval Plans, 15.

16. Ibid., 13. 
17. Ibid., [flyer].

18. Association of Research Libraries, Approval Plans in ARL Libraries, [flyer].

19. Brian Alley, "A Conversation with Jim Cameron," Technicalities 4 (July 1984): 4.

20. Kathleen McCullough, Edwin D. Posey, and Doyle C. Pickett, Approval Plans and Academic Libraries: An Interpretive Survey, Neal-Schuman Professional Books (Phoenix, Ariz.: Oryx, 1977), 30.

21. Association of Research Libraries, Approval Plans, 11.

22. The trend is graphically portrayed in Sarah M. Pritchard's and Eileen Finer's, $A R L$ Statistics, 1990-91, Washington, D.C.: Association of Research Libraries, 1992, 6.

23. Hugh C. Atkinson, "Faculty Reaction to New Approval Plan at the Ohio State University," in Approval and Gathering Plans in Academic Libraries, 35.

24. Association of Research Libraries, Approval Plans in ARL Libraries, 4.

25. For a case study of an approval plan involving faculty, see Ann Niles, "An Approval Plan Combined with Faculty Selection," in Collection Development in College Libraries, ed. Joanne Schneider Hill, William E. Hannaford, Jr., and Ronald Epp (Chicago: ALA, 1991), 163-69.

26. Robert J. Dukes, Jr., "Faculty/Library Relations in Acquisitions and Collection Development: The Faculty Perspective," Library Acquisitions: Practice \& Theory 7 (1983): 223.

27. William A. Wortman, Collection Management: Background and Principles (Chicago: ALA, 1989), 140.

28. Daniel Gore, "Adopting an Approval Plan for a College Library: The Macalester College Experience," in Economics of Approval Plans, 24. The rise of "collection management" has for many librarians moved the focus away from selection of individual titles: Charles W. Brownson, "Mechanical Selection," Library Resources \& Technical Services 32 (Jan. 1988): 17-29; John C. Calhoun, James K. Bracken, and Kenneth L. Firestein, "Modeling an Academic Approval Program," Library Resources \& Technical Services 34 (July 1990): 367-79; James A. Cogswell, "The Organization of Collection Management Functions in Academic Research Libraries," Journal of Academic Librarianship 13 (Nov. 1987): 268-76.

29. The 1964/65 annual report of UCLA's university librarian, which reported that despite certain problems, approval plans had reduced by 29.8 percent the number of invoices processed, was excerpted in Library Journal and no doubt widely read: "Publishers, Computers, \& Consumers," Library Journal 91 (Mar. 15, 1966): 1365.

30. Association of Research Libraries, Approval Plans in ARL Libraries, 4.

31. For discussion of the political context of collection development, see Ross Atkinson, "Old Forms, New Forms: The Challenge of Collection Development," College \& Research Libraries 50 (Sept. 1989): 507-20; Wilmer H. Batz, "Collection Development in 19 Libraries of the Association of Research Libraries," Library Acquisitions: Practice \& Theory 2 (1978): 117; Scott R. Bullard, "Read My Lips: The Politics of Collection Development," Library Acquisitions: Practice \& Theory 13 (1989): 251-53; Peggy Johnson, "Collection Development Officer, a Reality Check: A Personal View," Library Resources \& Technical Services 33 (Apr. 1989): 153-60; Albert Perdue, "Conflicts in Collection Development," Library Acquisitions: Practice \& Theory 2 (1978): 123-26. For acquisitions, see Joe A. Hewitt, "On the Nature of Acquisitions," Library Resources \& Technical Services 33 (Apr. 1989): 105-22.

32. The process of writing a profile often, however, proves beneficial: Noreen S. Alldredge, "The Symbiotic Relationship of Approval Plans and Collection Development," in Shaping Library Collections for the 1980s, 174-77; Eric J. Carpenter, "Collection Development Policies Based on Approval Plans," Library Acquisitions: Practice \& Theory 13 (1989): 39-43.

33. Vendor representatives, who must always be aware of library politics, have often commented upon the political aspects of approval plans: Dana L. Alessi, "Coping with Library Needs: The Approval Vendor's Response/Responsibility," in Issues in Acquisitions: Programs \& Evaluation, ed. Sul H. Lee, Library Management Series (Ann Arbor, Mich.: Pierian, 1984), 101-2; Dimity S. Berkner, "Considerations in Selecting an Approval Plan," in Shaping Library Collections for the 1980s, 148-49; Gloria Frye and Marcia Romanansky, "The Approval Plan-The Core of an Academic Wholesaler's Business," in Issues in Acquisitions: Programs \& Evaluation, 118-19; Doyle C. Pickett, "Approval Plans: 
A Supplier's View," in McCullough, Approval Plans and Academic Libraries: An Interpretive Survey, 139; R. Charles Wittenberg, "The Approval Plan: An Idea Whose Time Has Gone? And Come Again?" Library Acquisitions: Practice \& Theory 12 (1988): 239.

34. Dennis R. Brunning, "Troubleshooting the Approval Plan: A Case Study from the Subject Specialist's Point of View," in Libraries and the Literacy Challenge: The Frontier of the'90s, ed. V. Sue Hatfield (Emporia, Kans.: Emporia State Univ., 1987), 93.

35. One manual mentions only the analysis of return rates, using the vendor's management reports: Blaine H. Hall, Collection Assessment Manual for College \& University Libraries (Phoenix, Ariz.: Oryx, 1985), 81-84. A review of a different manual on approval plan management praised the work for "the constant emphasis on the importance of public relations," while faulting it for giving almost no attention to the evaluation of vendor performance: Mildred M. Franks, review of Practical Approval Plan Management, by Jennifer S. Cargill and Brian Alley, in Library Acquisitions: Practice \& Theory 4 (1980): 274. For an optimistic view of the practicability of precise evaluation, see Gary M.Shirk, "Evaluating Approval Plan Vendor Performance: Toward a Rationale and Model," in Issues in Acquisitions: Programs \& Evaluation, 11-31. See note 33.

36. On this question see Joseph W. Barker, "Vendor Studies Redux: Evaluating the Approval Plan Option from Within," Library Acquisitions: Practice \& Theory 13 (1989): 133-41; Sharon Bonk and Mina B. LaCroix, "Approval Plans in a Developing University Library 1970-79: A Case Study," in Shaping Library Collections for the 1980s, 32-42.

37. Dobbyn, "Approval Plan Purchasing in Perspective," 194; Robert C. Miller, "Approval Plans: Fifteen Years of Frustration and Fruition," in Shaping Library Collections for the 1980s, 50; Edwin D. Posey, "The Approval Plan Experience of an Engineering Library," in Shaping Library Collections for the 1980s, 112-13.

38. Brunning, "Troubleshooting the Approval Plan," 106; Linda Ann Hulbert and David Stewart Curry, "Evaluation of an Approval Plan," College \& Research Libraries 39 (Nov. 1978): 491.

39. Two other examples are: Mary Lee DeVilbiss, "The Approval-Built Collection in the Medium-Sized Academic Library," College \& Research Libraries 36 (Nov. 1975): 487-92; Peter B. Kaatrude, "Approval Plan versus Conventional Selection: Determining the Overlap," Collection Management 11 (1989): 145-50.

40. Hulbert and Curry, "Evaluation of an Approval Plan," 485.

41. Ibid., 488-89.

42. Ibid., 491.

43. Linda A. Hulbert, letter to the editor of College \& Research Libraries 40 (Sept. 1979): 461.

44. Two studies failing to discuss this question are: Joan Grant and Susan Perelmuter, "Vendor Performance Evaluation," Journal of Academic Librarianship 4 (Nov. 1978): 366-67; Mary D. Walter, "Approval Program Timing Study: Baker \& Taylor vs. Blackwell North America," Collection Building 7 (Spring 1985): 14-18.

45. Gloriana St. Clair and Jane Treadwell, "Science and Technology Approval Plans Compared," Library Resources \& Technical Services 33 (Oct. 1989): 385.

46. Hugh Franklin, "Engineering Books on Approval: A Selector's Viewpoint," Technicalities 9 (Mar. 1989): 13.

47. Association of Research Libraries, Approval Plans in ARL Libraries, 28-29.

48. Kay Womack and others, "An Approval Plan Vendor Review: The Organization and Process," Library Acquisitions: Practice \& Theory 12 (1988): 376.

49. Brunning, "Troubleshooting the Approval Plan," 100, 106.

50. For example by Paul H. Mosher, "Waiting for Godot: Rating Approval Service Vendors," in Shaping Library Collections for the 1980s, 160.

51. Such a venture was reported over ten years ago: Sylvia N. Schnaars, "The Bryn Mawr/Haverford Joint Approval Plan: Can Two Live as Cheaply as One?" in Shaping Library Collections for the 1980s, 59-68. 


\section{Be a PR Star! Enter the 1994}

\section{JOHN COTTON DANA LIBRARY PUBLIC RELATIONS AWARDS CONTEST}

IF YOU'VE DONE an outstanding job of making your community more aware of your library, the John Cotton Dana Library Public Relations Awards Contest can tell the world about your efforts.

Your entry will be considered among those from libraries of all types, sizes, and budgets. Entries are judged by a panel of your peers, and two types of awards are given.

\section{The John Cotton Dana Award}

This award is given for a library's total annual coordinated public relations program, including publicity, programs, advertising, publications, exhibits, special events, promotions, and audio-visual presentations.

\section{The Special Award}

The Special Award is given in recognition of a part of your public relations program-a fund-raising campaign, a series of adult or children's programs, or any other special project.

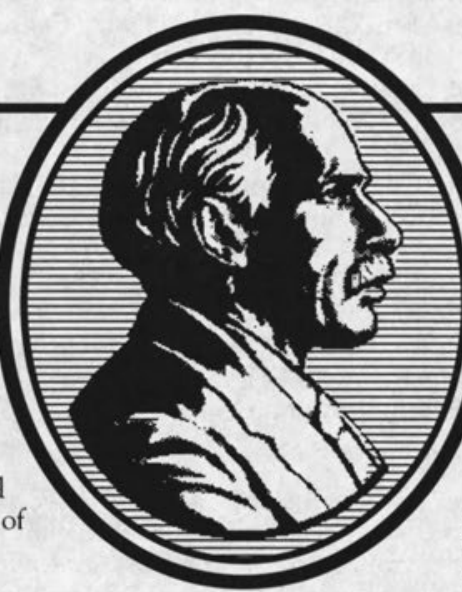

\section{Contest Dates}

Entries for the 1994 John Cotton Dana Library Public Relations Awards Contest can reflect any one of the following time frames:

- Calendar year 1993 (January-December)

- School Year 1992/93 (Fall-Spring)

- Special Project which ends in 1993.

The Deadline for entries is February 7, 1994.

\section{Awards Ceremony}

Official award citations will be presented to contest winners at the 1994 annual conference of the American Library Association, at a reception hosted by The H.W. Wilson Company.

\section{Sponsorship}

The John Cotton Dana Library Public Relations Awards Contest is sponsored jointly by The H.W. Wilson Company and the Public Relations Section of the Library Administration and Management Association, a division of the American Library Association.

\section{To Enter}

To request an Information Packet containing contest entry forms, rules and regulations, questions and answers about the awards, a sample of the judges' evaluation form, names of the contest judges, and a list of previous winners, please write to: John Cotton Dana PR Awards Contest, The H.W. Wilson Company, 950 University Avenue, Bronx, New York 10452. 